\title{
REVISITING THE 'REFORMED OBJECTION' TO NATURAL THEOLOGY
}

\author{
MICHAEL SUDDUTH
}

San Francisco State University

\begin{abstract}
In the present paper I address two significant and prevalent errors concerning opposition to natural theology within the Reformed theological tradition. First, contrary to Alvin Plantinga, I argue that the idea of properly basic theistic belief has not motivated or otherwise grounded opposition to natural theology within the Reformed tradition. There is, in fact, a Reformed endorsement of natural theology grounded in the notion that theistic belief can be properly basic. Secondly, I argue that late nineteenth- and twentieth-century Reformed criticisms of natural theology do not constitute an objection to natural theology as such but rather an objection to natural theology construed in a particular way. I explore the nature of this objection and its compatibility with an alternative understanding of natural theology.
\end{abstract}

The so-called 'Reformed objection' to natural theology has been the focal point of a plethora of essays in Anglo-American philosophy of religion since the emergence of the Reformed epistemology movement spearheaded by Alvin Plantinga and Nicholas Wolterstorff in the early I980s. 'Natural theology' in this context refers to the project of developing rational arguments for the existence and nature of God. The 'Reformed objection' refers to opposition to this project associated with the Calvinistic or Reformed streams of the Protestant theological tradition. In this paper I will revisit the Reformed objection to natural theology.

My primary goal in this paper is to put the Reformed objection to natural theology in proper perspective, and this requires correcting two significant and long-standing misunderstandings concerning Reformed opposition to natural theology. First, contrary to what Alvin Plantinga has argued, the thesis of properly basic theistic belief has not motivated or otherwise grounded any Reformed objection to natural theology. Quite the contrary, I will argue. The idea that human persons have 
a natural disposition to believe in God in a basic way has actually inspired a Reformed endorsement of natural theology - a frequently overlooked aspect of the Reformed tradition. Secondly, Reformed criticisms of natural theology have typically not targeted the project of natural theology as such but rather a certain construal of this project. At any rate, this is true of what is arguably the central Reformed objection to natural theology, what I will designate the autonomy objection. This objection targets natural theology as system of theology entirely separate from or independent of dogmatic theology, but I will argue that natural theology may be (and has been) otherwise construed and so insulated from the autonomy objection. In the latter part of the paper I outline a model of natural theology according to which natural theology is a vital element within the discourse of dogmatic theology. Consequently, the autonomy objection should be viewed as a call to recontextualize natural theology as opposed to being a demand that we reject it altogether.

\section{THE REFORMED OBJECTIONTO NATURAL THEOLOGY}

\section{A. The 'Reformed Objection' in Perspective}

Since the I980s it has become increasingly fashionable in Anglo-American philosophy of religion to associate the Reformed tradition in general with opposition to natural theology, as if the majority of Reformed theologians have rejected theistic arguments or such a rejection has been the dominant position of the tradition. Alvin Plantinga and Nicholas Wolterstorff have popularized this idea, but earlier twentieth-century thinkers, for example Edgar Sheffield Brightman and Robert Leet Patterson, suggested it as well. ${ }^{1}$

\footnotetext{
${ }^{1}$ See Alvin Plantinga, “The Reformed Objection to Natural Theology," Proceedings of the American Catholic Philosophical Association, I5 (I980): 49-63; Nicholas Wolterstorff, "The Reformed Tradition" in A Companion to Philosophy of Religion, ed. Philip Quinn and Charles Taliaferro (Oxford: Blackwell Publishers, I999), I66; Edgar Sheffield Brightman, A Philosophy of Religion (New York: Prentice Hall, 1940), 23-5, 172; Robert Leet Patterson, An Introduction to the Philosophy of Religion (New York: Holt and Company, I958), I42.
} 
Plantinga has written:

Suppose we think of natural theology as the attempt to prove or demonstrate the existence of God. This enterprise has a long and impressive history.... Many Christians, however, have been less than totally impressed. In particular Reformed or Calvinistic theologians have for the most part taken a dim view of this enterprise. A few Reformed thinkers-B.B. Warfield, for exampleendorse the theistic proofs; but for the most part the Reformed attitude has ranged from tepid endorsement, through indifference, to suspicion, hostility, and outright accusations of blasphemy. ${ }^{2}$

Similarly, Nicholas Wolterstorff has said, "Characteristic of the Continental Calvinist tradition has been a revulsion against arguments in favor of theism or Christianity." Wolterstorff has spoken of the rejection of the possibility of natural theology by "the bulk of Reformed theologians" and linked this to the work of contemporary philosophers of religion in the Reformed tradition:

One of the most salient features of contemporary philosophy of religion in the Reformed tradition of Christianity is its negative attitude toward natural theology - this negative attitude ranging all the way from indifference to hostility. In this regard, the philosophers of the tradition reflect the dominant attitude of the theologians of the tradition, going all the way back to its most influential founder, John Calvin. ${ }^{5}$

It is important to emphasize at the outset that Reformed thought has not opposed natural theology to the extent that contemporary philosophers of religion have suggested. Up until the latter part of the nineteenth century, natural theology was widely endorsed within the Reformed

${ }^{2}$ Alvin Plantinga, "Reason and Belief in God," in Faith and Rationality: Reason and Belief in God, ed. Alvin Plantinga and Nicolas Wolterstorff (Notre Dame: University of Notre Dame Press, 1983), 63. A portion of this essay was originally published as "The Reformed Objection to Natural Theology," Proceedings of the American Catholic Philosophical Association, I5 (1980): 49-63. Since the 1983 reproduction of this material in "Reason and Belief in God" is more widely accessible than the original 1980 article, references and quotations will be taken from the 1983 article.

${ }^{3}$ Nicholas Wolterstorff, "Introduction," in Faith and Rationality, 7.

${ }^{4}$ Nicholas Wolterstorff, "The Reformed Tradition,” I66.

${ }^{5}$ Ibid., I65. 
tradition. Rev. John Platt has carefully delineated the endorsement and development of theistic arguments in early Reformed scholasticism, and Richard Muller has explained its development from the Reformation period through eighteenth-century Reformed scholasticism. ${ }^{6}$ It is also worth noting that several of the major nineteenth-century works on the history of natural theology do not describe any Calvinistic or Reformed objection to natural theology, though they consider religious objections to natural theology in some detail. Calvinists, when mentioned, are depicted as supporters of natural theology. ${ }^{7}$ As a widespread phenomenon in the tradition, the Reformed rejection of natural theology appears to be a latecomer on the Reformed theological scene. And even here we must proceed with caution, as the legitimate lines of dispute, where they exist, have typically been drawn around the function of theistic arguments not their basic acceptance. As I'll argue later in this paper, this is true even in the viewpoint of the harsher nineteenth- and twentieth-century Reformed critics of natural theology.

\section{B. Plantinga' 'Reformed Objection'}

While contemporary philosophers of religion have exaggerated the extent of objections to natural theology in the Reformed tradition, we must still recognize that some prominent representatives of the tradition have objected to natural theology. Nineteenth-century Dutch neo-Calvinists

\footnotetext{
${ }^{6}$ Richard A. Muller, Post-Reformation Reformed Dogmatics: The Rise and Development of Reformed Orthodoxy, ca. 1520 to ca. 1575, $2^{\text {nd }}$ edition (4 vols, Grand Rapids: Baker Book House, 2003), vol. I, 270-310, vol 3, 153-226; John Platt, Reformed Thought and Scholasticism: the Arguments for the Existence of God in Dutch Theology, 1575-I650 (Leiden: E.J. Brill, I982). See also my Reformed Objection to Natural Theology (Farnham: Ashgate Publishing Limited, 2009), chapter I.

${ }^{7}$ See Alfred Caldecott, The Philosophy of Religion in England and America (London: Methuen \& Co., I90I), I05-45, 400-4I5; Thomas Flint, Theism, $7^{\text {th }}$ edition (1877; reprint, New York, Charles Scribner's Sons, I90I), 323-9; E.H. Gillett, God in Human Thought (2 vols, New York: Scribner, Armstrong, \& Co., I874), vol. 2, 422, 468-71, 487-93, 508-I6, 676-79; Lewis Ezra Hicks, Critique of Design-Arguments, A Historical Review and Free Examination of the Methods of Reasoning in Natural Theology (New York: Charles Scribner's Sons, 1883), I64-74, 187-95, 243-77, 283-87,309-30; Bernard Pünjer, History of the Christian Philosophy of Religion from the Reformation to Kant, trans. W. Hastie (Edinbugh: T \& T Clark, 1887), I25-58.
} 
Abraham Kuyper and Herman Bavinck, for example, were highly critical of 'theistic proofs.' Reformed criticisms of natural theology have been widespread in twentieth-century Reformed thought. Auguste Lecerf, G.C. Berkouwer, G.H. Kersten, Karl Barth, William Masselink, and Cornelius Van Til are six such prominent critics.

In several articles since 1980 Alvin Plantinga has examined the critical appraisal of natural theology among three representative Reformed theologians: John Calvin, Herman Bavinck, and Karl Barth. ${ }^{8}$ Plantinga's main conclusion has been that these thinkers rejected natural theology primarily because they held that theistic belief is properly basic, that is, theistic belief can be rational (and even constitute knowledge) for a person, even if the person does not have arguments or evidence for theistic belief, indeed, even if no such arguments are available.

In rejecting natural theology, therefore, these Reformed thinkers [Calvin, Bavinck, and Barth] mean to say first of all that the propriety or rightness of belief in God in no way depends upon the success or availability of the sort of theistic arguments that form the natural theologian's stock in trade. I think this is their central claim here, and their central insight. ${ }^{9}$

Furthermore, according to Plantinga, adhering to the proper basicality of theistic belief as these thinkers did, they were led to an inchoate rejection of classical foundationalism. Classical foundationalism is the epistemological view that all chains of inferentially justified beliefs ultimately terminate in properly basic propositions that are self-evident, evident to the senses, or incorrigible. Since theistic belief does not satisfy any of these criteria of proper basicality, if theistic belief is supposed to be properly basic, classical foundationalism must be mistaken. So, as Plantinga sees it, the alleged rejection of natural theology by Reformed theologians is closely connected to their at least implicit rejection of classical foundationalism.

Plantinga raises three additional points, largely in connection with Dutch Calvinist Herman Bavinck. As Plantinga sees it, Bavinck

\footnotetext{
${ }^{8}$ In addition to "The Reformed Objection to Natural Theology" and "Reason and Belief in God," “The Reformed Objection Revisited," Christian Scholar's Review, I2 (I983): 57-6r.

${ }^{9}$ Plantinga, "Reason and Belief in God," 72.
} 
maintained that we cannot come to a knowledge of God's existence by way of arguments because theistic arguments simply do not work. Secondly, the Bible does not argue to God's existence but rather presupposes it; therefore, the Christian should start from belief in God rather than reason to God's existence. Or, as Plantinga subsequently states the matter, theistic belief ought not to be based on arguments. Finally, belief in God is analogous to belief in the existence of the self and the external world. We typically do not have, and do not need, arguments for the latter kinds of beliefs. We hold them, and properly so, in a basic way. The same is true of theistic belief. ${ }^{10}$

\section{PROPER BASICALITY AND NATURAL THEOLOGY}

The first thing to see here is that Plantinga is correct that the Reformed tradition has asserted the proper basicality of theistic belief, or at any rate, something closely approximating it. Calvin's sensus divinitatis is plausibly interpreted as a non-inferential, spontaneous conviction of the existence of God. Bavinck, as Plantinga points out, held that theistic belief does not originate with argument, but it is spontaneously formed, just like our belief in the self and the external world. Bavinck, though, is following an established tradition originating with the Reformers and developed by the Reformed scholastics. The latter spoke of the cognitio dei insita, that is, the naturally implanted knowledge of God. This knowledge stands in contrast to knowledge of God acquired by way of reasoning or inference.

As Louis Berkhof described the cognitio dei insita:

It denotes a knowledge that necessarily results from the constitution of the human mind, that is inborn only in the sense that it is acquired spontaneously, under the influence of the semen religionis implanted in man by his creation in the image of God, and that is not acquired by the laborious process of reasoning and argumentation. ${ }^{11}$

\footnotetext{
${ }^{10}$ See Plantinga, "Reason and Belief in God," 65, 72.

${ }^{11}$ Louis Berkhof, Systematic Theology, $4^{\text {th }}$ edition (1939; reprint, Grand Rapids: Eerdmans Publishing Co., 1984), 35.
} 
It is a frequently overlooked fact that Princeton theologians Charles Hodge and B.B. Warfield, otherwise known for their endorsement of natural theology, held that the existence of God is an intuitive truth, not something belief in which originates from argument or a process of reasoning. ${ }^{12}$ William Shedd and Augustus Strong similarly held that we know that God exists by means of a rational intuition. ${ }^{13}$ The awareness of God's existence spontaneously arises in us with our self-knowledge and experience of the world. Since this knowledge of God is immediate, not the product of inference or argument, it involves theistic beliefs that are-in Plantinga's language-properly basic. So Plantinga is correct when he speaks of the Reformed commitment to the proper basicality of theistic belief. The above theologians illustrate a widely accepted idea within the Reformed tradition.

\section{A. Proper Basicality and the Rejection of Natural Theology}

What seems implausible, though, is Plantinga's idea that the Reformed commitment to properly basic theistic belief has motivated or otherwise involved a rejection of natural theology. I'll argue this in a preliminary way here and return to it in section III.C.

First, there is the following conceptual point: the proper basicality thesis does not entail a denial of the value or usefulness of theistic arguments, so it is exceedingly difficult to see how the proper basicality thesis can adequately motivate a rejection of natural theology in point of logic. This is true even if we restrict our focus to the epistemic value of such arguments. The proper basicality thesis, at least in its standard form, states that some theistic beliefs can have some (perhaps highly exalted) positive epistemic status for some people under certain conditions in the absence of natural theology. This is properly speaking a denial of certain strong forms

${ }^{12}$ Charles Hodge, Systematic Theology (3 vols, n.d.; reprint, Grand Rapids: Eerdmans Publishing Company, I982), vol. I, I9I-203; B.B. Warfield, "God," in Studies in Theology, vol. 9 of The Works of Benjamin B. Warfield (Io vols, 1932; reprint, Grand Rapids: Baker Book House, 2000), ilo.

${ }^{13}$ William Shedd, Dogmatic Theology, $2^{\text {nd }}$ edition (3 vols, I888; reprint, Nashville: Thomas Nelson Publishers, I980), vol. I, I95-220; Augustus Strong, Systematic Theology (1907; reprint, Valley Forge, PA: Judson Press, 1979), 52-70. 
of theistic evidentialism, not natural theology. The project of developing theistic arguments, and the belief that such arguments are epistemically efficacious, must be distinguished from the epistemological view that there can be no knowledge of God without such arguments. Of course, natural theology might still be necessary in a more restricted sense. For example, natural theology might be necessary for people to be warranted in particular kinds of theistic beliefs, for example, of a theoretically robust sort. Or natural theology might be necessary for warranted theistic belief for some people under highly specific circumstances, for example, where people have acquired a defeater for theistic belief. ${ }^{14}$ Moreover, theistic arguments may be useful to Christian apologetics for the purpose of showing that theism is true, however such arguments are implicated in the theist's knowledge of God.

Of course, Plantinga also says that according to theologians such as Bavinck belief in God ought not to be based on argument.

In fact, they [Calvin, Kuyper, Bavinck, and Barth] think that the Christian ought not to accept belief in God on the basis of argument; to do so is to run the risk of a faith that is unstable and wavering.... The correct or proper way to believe in God, they thought, was not on the basis of arguments from natural theology or anywhere else; the correct way is to take belief in God as properly basic. ${ }^{15}$

This is a stronger claim than the standard proper basicality thesis. How should we understand it? I think the protest here is against inference being the exclusive source of belief in God. Or more precisely stated, a cognizer whose relevant cognitive faculties are functioning properly does not come to believe in God solely on the basis of argument, and for such a person belief in God will not be sustained solely by argument. We need only slightly adjust this to leave more room for natural theology. A believer who reflects sufficiently on the matter may derive more robust sorts of theistic beliefs by way of logical inference, for example, belief in divine simplicity or God's timelessness. These beliefs will depend on argument, perhaps

\footnotetext{
${ }^{14}$ On defeaters and natural theology, see my Reformed Objection to Natural Theology, 88-92.

${ }^{15}$ Plantinga, "Reason and Belief in God," 72.
} 
exclusively so. I do not think that Bavinck in particular or the Reformed tradition in general is claiming that there is something improper about this. The believer may very well need arguments for these kinds of theistic beliefs. The idea here rather is that belief in God simpliciter ought not to be exclusively grounded in argument.

Secondly, Reformed theologians have in fact recognized inference as a source of natural knowledge of God. Following Reformers such as Philip Melanchthon, Martin Bucer, Peter Martyr Vermigli, and John Calvin, Reformed orthodoxy has distinguished between knowledge of God that is naturally implanted in the human person (cognitio dei insita) and knowledge of God that is acquired by rational inference from observational features of the world, such as its order and beauty (cognitio dei acquisita). ${ }^{16}$ Francis Turretin wrote: "The orthodox. . .uniformly teach that there is a natural theology, partly innate (derived from the book of conscience by means of common notions) and partly acquired (drawn from the book of creatures discursively). ${ }^{17}$ According to this model, the natural knowledge of God-generally speaking-is not exclusively immediate, nor exclusively inferential. Theistic inferences operate in tandem with immediate knowledge of God. We might even say that the former confirms and supplements the latter. We are also not committed to supposing that we first come to believe in God by way of inference.

Consider the testimony of four Calvinists at this juncture. Charles Hodge, optimistic as he was about theistic arguments, did not see such arguments as the origin of belief in God. After affirming that the existence of God is an intuitive truth, Hodge says: "We do not thus reason ourselves into the belief that there is a God; and it is very obvious that it is not by such a process of ratiocination, simple as it is, that the mass of people are brought to this conclusion." 18 Theistic proofs are the product of "the method by which that [intuitive] belief is confirmed and developed." ${ }^{19}$

${ }^{16}$ On the distinction between the cognitio dei insita and cognitio dei acquisita, see Turretin, Institutes of Elenctic Theology, trans. G.M. Giger (3 vols, Phillipsburg: P\&R Publishing, 1992), I.2.7, I.3.I-6; Bavinck, Reformed Dogmatics, trans. J. Vriend (2 vols, Grand Rapids: Baker Academic, 2003-2004), vol. 2, 59-76; Berkhof, Systematic Theology, 35-6.

${ }^{17}$ Turretin, Institutes of Elenctic Theology, I.3.4.

${ }^{18}$ Hodge, Systematic Theology, vol. I, 200.

${ }^{19}$ Ibid. 
William Shedd said that theistic arguments "assist the development of the idea of God, and contain a scientific analysis of man's natural consciousness of the deity."20 Similarly, B.B. Warfield, "This immediate perception of God is confirmed and the contents of this idea developed by a series of arguments known as "theistic proofs."' ${ }^{11}$ Finally, Calvinistic Baptist Augustus Strong wrote, "Although the knowledge of God's existence is intuitive, it may be explicated and confirmed by arguments drawn from the actual universe and from the abstract ideas of the human mind." 22

Herman Bavinck held a similar view. Although he acknowledged a cognitio dei insita, he also maintained a cognitio dei acquisita. As Bavinck sees it, God reveals Himself to human consciousness in an intuitive manner by way of the cognitio dei insita.

In the case of the acquired knowledge of God, human beings reflect upon that revelation of God. Their minds go to work, thought processes are set in motion, and with clear heads they seek by reasoning and proof to rise from the observation of creatures to [the reality] of God. The fact is, humans are not content with impressions and intuitions in any area of knowledge... They desire to explain the how and why of their knowledge. Common everyday empirical knowledge is always driven to achieve true, scientific, knowledge. That is also why faith aspires to become theology, and the innate knowledge of God seeks to complete itself in the acquired knowledge of God. ${ }^{23}$

Bavinck and these other Reformed theologians are representative of Reformed thought at this juncture. Commitment to immediate knowledge of God does not motivate the rejection of theistic arguments. Quite the contrary: theistic arguments are typically taken to represent the reflective elaboration of a more primitive, spontaneous knowledge of God, and the human impulse towards reflective knowledge is itself as natural as the impulse to believe in God. Natural theology is therefore a consequence of our constitution as human persons.

\footnotetext{
${ }^{20}$ Shedd, Dogmatic Theology, vol. I, 22I.

${ }^{21}$ B.B. Warfield, "God," Iıо.

${ }^{22}$ Strong, Systematic Theology, 7I.

${ }^{23}$ Bavinck, Reformed Dogmatics, vol. 2, 74 .
} 


\section{B. The Reformed Endorsement of Natural Theology}

The Reformed account of the natural knowledge of God confronts us squarely with an endorsement of the project of natural theology. The above Reformed theologians, including Bavinck, accept the project of developing theistic arguments. In this they are representative of the tradition as a whole. Bavinck confirms this in saying, "natural theology is upheld in its truth and value by all Reformed theologians." 24 Again, "Reformed theologians from the very beginning adopted a friendlier posture toward natural theology." ${ }^{25}$ What is initially surprising here is that a critic of natural theology takes this position.

What, then, of Plantinga's claim that Bavinck thinks that theistic arguments don't work? “. . . [W] cannot come to knowledge of God on the basis of argument; the arguments of natural theology just do not work." ${ }^{26}$ There is a sense in which Plantinga is correct. Late nineteenthand twentieth-century Reformed theologians have often been skeptical of theistic arguments as ostensible 'proofs' or 'logical demonstrations,' that is, as rationally compelling arguments for the existence of God. The arguments don't work in this respect. (Of course several of the leading natural theologians of our day would agree with this assessment of natural theology. ${ }^{27}$ Bavinck was explicit about the failure of theistic arguments as purported logical demonstrations, ${ }^{28}$ but at the same time he maintained that these arguments are effective in other respects. First, they are stronger than arguments against the existence of God. As such they are apologetically relevant and useful. ${ }^{29}$ Moreover, although weak as proofs, these arguments are strong as 'signs and testimonies' that never fail to make an impression on everyone's mind." 30 What Bavinck means to say here, I think, is that theistic arguments involve evidences that confirm the intuitive perception of God and are instrumental in developing this basic

\footnotetext{
${ }^{24}$ Bavinck, Reformed Dogmatics, vol. I, 87 .

${ }^{25}$ Bavinck, Reformed Dogmatics, vol. 2, 66.

${ }^{26}$ Plantinga, "Reason and Belief in God," 65.

${ }^{27}$ For example, Richard Swinburne, The Existence of God, $2^{\text {nd }}$ edition (Oxford: Clarendon Press, 2004), 4-22, 136-37, 155, 329-30.

${ }^{28}$ Bavinck, Reformed Dogmatics, vol. 2, 89-91.

${ }^{29}$ Ibid., vol. 2, p. 59; cf. 9 I.

${ }^{30}$ Ibid., vol. 2, 9I.
} 
knowledge. For Christians in particular theistic arguments confirm and clarify their own religious consciousness and allow them to systematically reflect on the revelation of God in nature.

For Christians these proofs signify that it is one and the same God who manifests himself in nature and in grace... Collectively, the testimonies that God sends us in the world and are condensed in the so-called proofs are nothing other than a revelation of the name of the Lord by means of which he makes himself known to his creatures and gives us the right to address him. ${ }^{31}$

Bavinck is not alone in this regard. Several prominent twentieth-century Reformed critics of natural theology affirm the value of theistic arguments as testimonies or evidences - not logical demonstrations - of the existence of God. As such, they are sufficient to rebut atheism and instrumental in confirming and developing the Christian's knowledge of God.

Concerning theistic arguments, Berkhof wrote:

They are important as interpretations of God's general revelation and as exhibiting the reasonableness of belief in a divine being. Moreover, they can render some service in meeting the adversary. While they do not prove the existence of God beyond possibility of doubt, so as to compel assent, they can be so constructed as to establish a strong probability and thereby silence many unbelievers. ${ }^{32}$

William Masselink argued that belief in God is not based on theistic arguments, either for the believer or unbeliever. The knowledge of God's existence comes to humans through the general witness of the Holy Spirit who makes the evidences of God in creation efficacious testimonies. But there is no process of logical inference at this level. Yet, Masselink still asserted the positive value of theistic arguments. "By means of these 'theistic proofs' it is not difficult to show the atheist not only the weak points of his system, but the hollow emptiness of his whole philosophy." 33 Moreover, since all people are endowed with an innate idea of God, the

\footnotetext{
${ }^{31}$ Ibid., vol. 2, 9I.

${ }^{32}$ Berkhof, Systematic Theology, 28.

${ }^{33}$ Masselink, General Revelation and Common Grace (Grand Rapids:Wm. B. Eerdmans Publishing Company, I953), II9.
} 
theistic arguments can also be used as "a stimulus to bring back Godconsciousness to the natural man. If the soul of the natural man then reacts to this stimulation, it can be a means to reawaken this God-consciousness within him." ${ }^{34}$ Finally, Masselink says that theistic arguments "strengthen the faith" and enable the believer to "come to a closer knowledge of God." ${ }^{35}$

According to G.H. Kersten, theistic arguments cannot prove the existence of God, especially not to unbelievers since "those who willfully suppress the conviction that God exists will not be convinced by any argument." ${ }^{36}$ However, these arguments are "not altogether worthless" if taken as testimonies. Kersten contends that theistic arguments can be of service simply to "entangle the atheist in his own statements. ${ }^{\text {" He says }}$ that theistic arguments "are testimonies that exceed in power the denial of the atheist." 38 Similarly, Auguste Lecerf affirmed the apologetic usefulness of theistic arguments. According to Lecerf, since faith seeks understanding, faith has an internal tendency to answer objections that might be urged against it. This is important not merely to fortify believers but also to be used by God as instruments in the conversion of the elect.

Apologetics does not endeavour to destroy the adversary's disposition to attack merely in order to comfort the believer; but, by the intellectual defence of religious truth which it presents, it seeks to become an instrument in God's hands, a means of grace, that shall produce in the opponent himself a deep and favourable impression of the truth of religious doctrine. ${ }^{39}$

Neither Bavinck nor his Reformed company here denies the value of theistic arguments, not even their epistemic efficacy. ${ }^{40}$ And this seems

\footnotetext{
${ }^{34}$ Ibid., II9.

${ }^{35}$ Ibid., I20.

${ }^{36}$ G.H. Kersten, Reformed Dogmatics: A Systematic Treatment of Reformed Doctrine (2 vols, I980; reprint, Netherlands Reformed Book and Publishing Committee, I98I),

${ }^{37}$ Ibid., 4r.

${ }^{38}$ Ibid., p. 42.

${ }^{39}$ Auguste Lecerf, An Introduction to Reformed Dogmatics (London: Lutterworth Press, I949), 208.

${ }^{40}$ Plantinga himself, while he expresses skepticism about theistic arguments being logical demonstrations, maintains that there are nonetheless good theistic arguments, and he asserts the usefulness of such arguments for various purposes, including confirming theistic
} vol. I, 37 . 
entirely right. We have a good deal of inferentially warranted beliefs and inferential knowledge based on arguments that fall short of being logical demonstrations. The same epistemic opportunities should apply to theistic belief. So we cannot infer that theistic arguments cannot be a source of positive epistemic status for theistic belief simply because such arguments do not work as logical demonstrations.

\section{THE AUTONOMY OBJECTION}

Seeing as Bavinck and these other Reformed critics of natural theology do not reject theistic arguments as such, in what sense do they object to natural theology? To be sure, they have a logical objection to theistic arguments. They believe such arguments fail as logical demonstrations. But is there more to their discontent with natural theology? Yes, but here is where we need an evaluation very different than the one Plantinga has provided.

\section{A. Natural Theology as a Separate and Foundational Theology}

In his Principles of Sacred Theology (1898) Abraham Kuyper expressed the following criticism of natural theology.

If at first the Reformation fostered more accurate ideas [about natural theology], soon the temptation appeared too strong, to place natural theology as a separate theology alongside of special theology (theologia specialis)....With this division it became apparent that the real Theology as knowledge of God gave the lion's share to natural theology. ... This furnished natural theology the occasion to unfold its wings even more broadly; to expand itself and lessen the importance of special theology; until finally it has succeeded in stepping forth as a monarch and in contesting all right of utterance to special theology. ... It is, therefore, of the greatest importance, to see clearly, that

belief and helping some people move from unbelief to belief. See Plantinga, "Reason and Belief in God," 73; "The Prospects for Natural Theology," in Philosophical Perspectives 5: Philosophy of Religion, ed. James Tomberlin (Atascadero: Ridgeview Publishing Co., I99I); and "Two Dozen (or So) Theistic Arguments" in Alvin Plantinga, ed. Deane-Peter Baker (Cambridge: Cambridge University Press, 2007), 203-27. 
special theology may not be considered a moment without natural theology, and that on the other hand natural theology of itself is unable to supply any pure knowledge of God. ${ }^{41}$

Kuyper does not here object to the project of developing theistic arguments. In fact, elsewhere he explicitly endorses such arguments. ${ }^{42} \mathrm{He}$ is also quite explicit that special or scriptural theology cannot do without natural theology. The former presupposes the latter, as grace presupposes nature. The focus of the criticism is the construction of a theology separate from the theology based on Scripture. As Kuyper sees it, natural theology historically evolved into an independent theology that usurped the authority of Scripture and ultimately undercut the notion of scriptural theology. Without the revelation of God in Scripture, though, theology is unable to supply any pure knowledge of God, for such a theology must always view God from the perspective of fallen human reason. Kuyper takes the noetic effects of sin to be significant enough to undermine the reliability of human reasoning about God, that is, in the absence of the light given by Scripture.

Natural theology can exhibit itself as a regnant power only when human nature receives the beams of its light in their purity and reflects them equally completely. At present, however, the glass has been impaired by a hundred cracks, and the receiving and the reflecting have become unequal, and the image that was to reflect itself is hindered in its clear reflection and thereby rendered untrue. And for this reason you cannot depend on natural theology as it works in fallen man; and its imperfect lines and forms bring you, through the broken image, in touch with the reality of the infinite, only when an accidens enables you to recover this defective ideal for yourself, and natural theology receives this accidens only in special revelation... ${ }^{43}$

Bavinck expressed similar concerns:

Now the Reformation indeed adopted this natural theology along with its proofs but, instead of treating it prior to the doctrine of faith, incorporated it

${ }^{41}$ Abraham Kuyper, Principles of Sacred Theology, trans. J. Hendrik De Vries (I898; reprint, Grand Rapids: Baker Book House, 1980), 372-73.

${ }^{42}$ Ibid., 243, 300, 302.

${ }^{43}$ Ibid., 307 . 
in the doctrine of faith.... Soon, however, Protestant theology started taking the road of rationalism. Whereas natural theology was initially an account, in the light of Scripture, of what Christians can know concerning God from creation, it soon became an exposition of what nonbelieving rational persons could learn from nature by the power of their own reasoning. . . .Natural theology became the real, the scientific and demonstrable theology by which revealed theology was increasingly marginalized and driven from the field. ${ }^{44}$

Like Kuyper, Bavinck's target here is natural theology as a system of theology developed in isolation from the content of Scripture. Bavinck is reacting to the actual evolution of natural theology in the history of Protestant dogmatics. As he sees it, natural theology as an independent theology supplemented by revealed theology quickly becomes an independent competitor to revealed theology. It ends up-as in English deism and German rationalism - thinking of itself as completely adequate and revealed theology as unnecessary. ${ }^{45}$ Bavinck too operates on the assumption that reason, without the assistance of Scripture, is incapable of properly reflecting on general revelation. Consequently, any theology based solely on general revelation will involve a fundamentally distorted view of God.

These concerns have been widespread in twentieth-century Calvinism. Speaking of the various treatises on natural theology composed by Reformed thinkers under the influence of Cartesianism, Auguste Lecerf said, "Natural theology is considered in them as an autonomous discipline, constituted solely by the resources of the light of nature and leading to the living God, the author of positive revelation. The function of revelation begins, once this truth has been acquired." ${ }^{46}$ Lecerf disapproves and adds, "Knowledge of God acquired by the spectacle of the universe, by the effect of reflection, if it is deprived of the help of positive revelation, is equally incapable of leading us to a correct theology." Kersten wrote, "Those who separate the natural knowledge of God from the special revelation

\footnotetext{
${ }^{44}$ Bavinck, Reformed Dogmatics, vol. 2, 78 .

${ }^{45}$ See Bavinck, Reformed Dogmatics, vol. I, 288, 306-20, 513.

${ }^{46}$ Lecerf, An Introduction to Reformed Dogmatics, 22.

${ }^{47}$ Ibid., I08.
} 
in Scripture are wrong when they see a separate entity in the 'theologia naturalis." 48

We see at this juncture a certain confluence of thought between these Calvinists and Karl Barth, for one of Karl Barth's objections to natural theology stemmed from the allegedly distorted view of God that results from creating an autonomous sphere of knowledge of God as creator that is wholly uninformed by the biblical doctrine of God.

It is. . hard to see how what is distinctive for this God can be made clear if, as has constantly happened in Roman Catholic and Protestant dogmatics both old and new, the question of who God is, which it is the business of the doctrine of the Trinity to answer, is held in reserve, and the first question to be treated is that of the That and the What of God, as though these could be defined otherwise than on the presupposition of the Who. ${ }^{49}$

In his General Revelation, G.C. Berkouwer also associated this sort of natural theology with Roman Catholicism. In a chapter devoted to a critique of the 'natural theology of Rome,' Berkouwer says:

The question now arises how and how far God is known in this way [through natural theology]. We have already seen that this knowledge cannot be adequate because it proceeds through the medium of created reality and is also characterized by it. So, for example, one cannot by means of natural knowledge know that God is triune. The mysteries are entirely hidden from such knowledge. It is apparent therefore, that this is not simply an inadequate knowledge, but that one must really speak of a partial knowledge, even in an extremely dualistic way. By means of natural knowledge one knows only that part or "aspect" of God which is mediated through creation and relates especially to his being. The results of the theistic proofs demonstrate this. By means of these proofs reason comes to recognize the existence of a self-existent being.... Here the knowledge relation between Creator and creature is ontologically fixed. It results in knowledge of the formal aspects of

${ }^{48}$ G.H. Kersten, Reformed Dogmatics, vol. I, 5 .

${ }^{49}$ Karl Barth, Church Dogmatics, ed. G.W. Bromiley and T.F Torrence (4 vols, Edinburgh: T \& T Clark, 1936-I975), vol. I. pt., I, pp. 300-30r. T.F. Torrance and Alister McGrath each argues that Barth's objection to natural theology was fundamentally the autonomy objection. See Torrance, "The Problem of Natural Theology in the Thought of Karl Barth,” Religious Studies 6 (1970): I2I-35; and McGrath, A Scientific Theology (Grand Rapids: Wm. B. Eerdmans Publishing Company, 2002), 267-86. 
God's being, in an independent natural theology of the first article (God as Creator) which has nothing to do with the knowledge of God in the reality of his grace and mercy....It is almost inconceivable that the Roman Catholic Church has not been repeatedly shocked by this empty, abstract, and formal God-concept of her natural theology. ... At this point Roman Catholic theology has never been able to give a satisfactory answer to Reformed critique. In this formal and empty God-concept we see the heart of Rome's natural theology. ${ }^{50}$

Berkouwer, like Barth but unlike most of the other Reformed thinkers mentioned above, has no place for theistic arguments at all, except as testimonies to the degenerated status of the natural knowledge of God. However, it is clear that he rejects theistic arguments precisely because he equates the project of developing such arguments with the creation of a purely rational system of theology that is unable to present God as $\mathrm{He}$ is in the totality of his revelation to creatures. Focusing solely on one aspect of the divine being reached by the intellect alone, the idea of God in natural theology becomes an intellectual idol.

What underlies the above critique of natural theology, then, are suspicions about natural theology as an autonomous theological system divorced from the content of special revelation. Such a system of theology is bound to be defective either because it involves a distorted knowledge of God as creator or excludes the knowledge of God as redeemer. The concern here is not merely a concern about systems of pagan natural theology, but even ostensibly Christian dogmatic theology that is erected on purely rational foundations. When approached independently of scriptural revelation, general revelation is bound to yield a theologically inadequate doctrine of God and His relation to created beings. Consequently, as Louis Berkhof aptly put it, the Reformers "did not believe in the ability of human reason to construct a scientific system of theology on the basis of natural revelation pure and simple." ${ }_{1}$

${ }^{50}$ Berkouwer, General Revelation (1955; reprint, Grand Rapids: Wm. B Eerdmans Publishing Company, 1979), 69, 72-73.

${ }^{51}$ Berkhof, Systematic Theology, 38 . 


\section{B. Pre-Dogmatic Foundations Model of Natural Theology}

It is important to see the above criticisms of natural theology as a reaction to a conception of natural theology that evolved out of the Enlightenment. The influence of Cartesianism on Protestant theology in the seventeenth century contributed to an expansion of the role of reason in theology. ${ }^{52}$ Natural theology became an autonomous system of rational theology that was intended as a pre-dogmatic foundation for the Christian faith. For example, Jean-Alphonse Turretin presented natural theology as a system of purely rational truths accessible to reason apart from any supernatural revelation. ${ }^{53}$ For Salomon van Til, natural theology was a prolegomenon in which a purely rational discourse on the divine existence and attributes, separated from Scripture, prepared the way for the system of revealed theology. ${ }^{54}$ The idea of a distinct rational-theological locus upon which the biblical doctrine of God could be based further evolved during the eighteenth century under the influence of Christian Wolff and Wolffian rationalism..$^{55}$ In the works of Johann Friedrich Stapfer and Daniel Wyttenbach, a detailed discussion of the existence and attributes of God constitutes the first port of entry to the doctrine of God, only subsequently followed by a discussion of Scripture and the Christian doctrine of God. ${ }^{56}$ In England, the Protestant response to Deism led many to erect a supernatural theology on the basis of a limited natural religion that encompassed the existence and attributes of God, as well as a range of moral duties accessible to reason,

\footnotetext{
${ }^{52}$ On the modern transformation of natural theology in Catholicism, see G. de Broglie, "La vraie notion thomiste des 'preambula fidei," Gregorianum 34 (I953):34I-89. On shifts in Protestant orthodoxy, see Bavinck, Reformed Dogmatics, vol. I, 87-9, I04-I08, 183-92, 287-89, 512-I7, and Muller, Post-Reformation Reformed Dogmatics, vol. 3, I38, 150, 193-95.

${ }^{53}$ See Martin I. Klauber, Between Reformed Scholasticism and Pan-Protestantism: JeanAlphonse Turretin (I67I-I737) and the Enlightened Orthodoxy at the Academy of Geneva (Selinsgrove: Susquehanna University Press, I994), chapter 3.

${ }^{54}$ Salomon van Til, Theologiae utriusque compendium (Leiden, I704, I719), I.i-iii, II.i-iii.

${ }_{55}$ See Muller, Post-Reformation Reformed Dogmatics, vol. I, 82-4, 174-76, 305-308, 396-98; vol. 3, pp. I2I-29, I4I-50, 193-95.

${ }^{56}$ Johann Friedrich Stapfer, Institutiones theologiae polemicae universae, ordine scientifico dispositae, $4^{\text {th }}$ ed. (5 vols, Zurich, I756-57), and Daniel Wyttenbach, Tentamen theologiae dogmaticae methodo scientifico pertractatae (3 vols, Frankfurt, I747-I749).
} 
as is illustrated in Richard Fiddes's Theologia Speculativa (I718) and Joseph Butler's Analogy of Religion (1736).

Bavinck nicely summarizes this intrusion of rationalism into Reformed thought:

The conviction took hold that human reason, even apart from faith, could of itself produce all the truths of natural theology. Thus, natural theology, as the preamble of faith, became antecedent to revealed theology, and reason was emancipated from faith and revelation. Revelation and reason became independent entities standing side by side.... Natural theology was believed to provide a solid ground on which to stand, a purely scientific foundation, and revelation too was examined this way. ${ }^{57}$

The nineteenth century would inherit this pre-dogmatic conception of natural theology, adjusted in various ways to counter the Kantian and Darwinian critique of traditional cosmological and design arguments. This arguably reached its culmination in the famous Gifford Lectures established by Lord Gifford in I888. Gifford's goal was to provide a platform for a purely scientific or rational treatment of the existence and nature of God, independent of any claims originating from an ostensible divine revelation. When late nineteenth and twentieth-century Reformed theologians objected to natural theology it is clear that most of them had this conception of natural theology in mind.

\section{Returning to Plantinga}

Earlier I had argued that Plantinga was mistaken to suppose that Reformed theologians such as Herman Bavinck rejected natural theology because they held that theistic belief is properly basic. We can now see another reason why Plantinga's diagnosis is mistaken. The central theme of Plantinga's analysis is the proper basicality thesis, namely the idea that theistic belief can have some positive epistemic status (e.g., rationality, knowledge) even in the absence of theistic arguments. But this is entirely compatible with the idea of an autonomous system of natural theology being the pre-dogmatic foundation for revealed theology. We have already

${ }^{57}$ Bavinck, Reformed Dogmatics, vol. I, Io5. See also Kersten, Reformed Dogmatics, vol. I, 4I. 
noted that the proper basicality thesis is compatible with the project of natural theology, but it is also compatible with viewing this project as an autonomous science that provides the rational foundations for revealed theology. The pre-dogmatic conception of natural theology may give the impression that proofs are preconditions for belief, but this is only an impression. One can affirm that, as far as personal belief goes, a person can be entirely reasonable in accepting God's existence in a basic way, even know that God exists in this way. The issue is really the proper logical starting point of theology, not the proper doxastic starting point for the individual believer. So the proper basicality thesis cannot be at the center of the Reformed objection to natural theology.

\section{THE DOGMATIC MODEL OF NATURAL THEOLOGY}

The autonomy objection is, I think, the central Reformed objection to natural theology. However, this objection clearly targets natural theology construed in a particular way. In contrast to the autonomous, pre-dogmatic conception of natural theology, there is what I will designate the dogmatic model of natural theology ${ }^{58}$ Roughly stated, according to this model of natural theology, theistic arguments represent a rational exploration and development of the content of natural revelation, but where this activity is situated in the context of dogmatic theology and thus guided by the data of scriptural revelation. Here natural theology would be part of the discourse of dogmatic theology not a preface to it. This was very much the way natural theology was originally conceived within the Reformed tradition.

\section{A. The Role of Theistic Arguments in Dogmatic Theology}

Theistic arguments made their first explicit appearance in Protestant theology in Philip Melanchthon's works. In his Commentary on Romans,

${ }^{58}$ I have borrowed the designation 'dogmatic model' from Richard Muller. See Muller, "The Dogmatic Function of St. Thomas' Proofs: A Protestant Appreciation”, Fides et Historia 24:2 (summer 1992): 15-29. 
theistic arguments appear as an elaboration and development of Romans I:I9-20. In his Loci Communes they appear under the heading de creatione, a biblically based discussion of creation. In each case, it is clear that theistic arguments are directed to the Christian as a means of rationally reflecting on the data of biblical revelation. They represent a scripturally informed meditation on natural revelation, not an attempt to lay rational foundations for faith. Melanchthon develops theistic arguments in the course of articulating aspects of revealed theology, with the stated goal of strengthening the Christian's knowledge of God. ${ }^{59}$ They are presented as Christian meditation on "the footprints of God in the nature of things." 60 Melanchthon says that God wants us to consider these testimonies since "it is useful for strengthening good opinions to hold fast to the true reasonings fixed in the mind, which testify that God is the founder and preserver of things." ${ }^{61}$ There is no attempt here to construct a theology of God based solely on reason.

In sixteenth and many seventeenth-century Protestant dogmatic systems theistic arguments were typically presented under theological prolegomena or the locus de Deo. ${ }^{62}$ In these systems, though, neither theological prolegomena nor the locus de Deo was pre-dogmatic in nature. Both exhibit a dependence on and integration with Scripture and the correlated Christian doctrine of God, even where the dogmatic system begins with the locus de Deo. This explains the reliance on Scripture in the locus de Deo, as is illustrated in the use of the "divine names" as a point of departure for articulating and systematizing the divine attributes ${ }^{63} \mathrm{It}$ also explains the inclusion of the doctrine of the Trinity under the locus de Deo, for example in Andreas Hyperius, Wolfgang Musculus, Lambert

${ }^{59}$ For a detailed discussion of natural theology in Melanchthon and Melanchthon's influence on subsequent Reformed dogmatics, see Platt, Reformed Thought and Scholasticism, chapter two.

${ }^{60}$ Philip Melanchthon, Commentary on Romans, trans. F. Kramer (Saint Louis: Concordia Publishing House, 1992), 77.

${ }^{61}$ Ibid.

${ }^{62}$ For a detailed discussion of theistic proofs in Reformed scholasticism, see Muller, Post-Reformation Reformed Dogmatics, vol. 3, 48-52, 153-95.

${ }^{63}$ See Muller, Post-Reformation Reformed Dogmatics, vol. 3, 254-72. 
Daneau, and Francis Turretin. ${ }^{64}$ In some instances the locus de scriptura is prior to the locus de Deo so it is clear that the doctrine of God rests on scriptural revelation as its foundation, not reason. We find this, for example, in Amandus Polanus, Edward Leigh, and Francis Turretin. ${ }^{65}$ Not surprisingly, we find no independent locus on natural theology, either within or prefaced to the theological system.

So, on the dogmatic view, natural theology is a dogmatically situated rational reflection on the Christian God as manifested in the works of creation and providence. One of the crucial functions of natural theology on this view is to assist in the enlargement and deepening of the Christian's knowledge of God specifically by reflecting on the content of natural revelation. Of course, such a function does not exclude the apologetic use of theistic arguments. Such a use was frequent among Reformed theologians of the early and high scholastic periods. In this context, though, theistic arguments would not be used to establish either theism or the Christian faith but simply to refute atheists and remove objections to the faith within the larger logical architecture of revealed theology. Francis Turretin and Edward Leigh, for example, used the proofs to refute atheists, but these arguments appear subsequent to the doctrine of Scripture under a biblically informed doctrine of God. This is, of course, entirely consistent with the instrumental use of reason in theology. There is a reasoned defense of the faith but no apologetically motivated theological prolegomenon in which natural theology is used to lay the foundations for subsequent claims about God derived from Scripture.

A dogmatic conception of natural theology also introduces the possibility of viewing theistic arguments as a way of justifying the instrumental role of reason within dogmatic theology ${ }^{66}$ From this vantage point, we can see theistic arguments as a way of exploring the nature of our knowledge of God and the possibility of a theological discourse in which there is a reasoned exploration and elucidation of the articles of faith. The proofs

${ }^{64}$ See Hyperius, Methodus theologiae (1568); Musculus, Loci communes (I560); Daneau, Christianae isogoges (1583); Turretin, Institutio theologiae elencticae (I679-85).

${ }^{65}$ For example, Polanus, Syntagma theologiae christianae (Geneva, I6I7), Leigh, Body of Divinity (London, 1654), and Turretin, Institutio theologiae elencticae (Geneva, I679-85).

${ }^{66}$ See Muller, Post-Reformation Reformed Dogmatics, vol. 3, 153-9; Muller, "The Dogmatic Function of St. Thomas'Proofs." 
provide reason to believe that reason itself can enter into the theological realm and elucidate the articles of faith. There is no need to establish the existence of God within the framework of the dogmatic system. Dogmatics presupposes the existence of God. There is a need, however, to establish the instrumental validity of reason for theology, to show that reason is fit for the task of being the handmaiden of sacred doctrine. On this view, while theistic arguments are intended as genuine arguments for the existence and nature of God, they are not foundations upon which revealed theology is built. They provide the Christian with a justification of the instrumental role of reason for the sake of the dogmatic elaboration of the articles of faith.

\section{B. Natural Theology Guided by Scripture}

According to the dogmatic model of natural theology, natural theological reasoning is situated within the context of scriptural revelation. It is important to emphasize that some of the Reformed critics of natural theology have explicitly endorsed this kind of natural theology, in addition to the apologetic function of theistic arguments.

Consider the following statement from Bavinck:

The Reformers indeed assumed a revelation of God in nature. But the human mind was so darkened by sin that human beings could not rightly know and understand this revelation. ... Objectively needed by human beings to understand the general revelation of God in nature was the special revelation of God in Holy Scripture, which, accordingly, was compared by Calvin to glasses.... Hence in the Reformation, natural theology lost its rational autonomy. It was no longer treated separately but incorporated in the doctrine of the Christian faith. ${ }^{67}$

How does Scripture guide natural theology? Fundamentally by providing a robust doctrine of God that will function as the framework for rational inquiry into the evidences for the being and attributes of God from created things. There are at least two closely related, complementary ways this framework can interact with natural theological reasoning.

${ }^{67}$ Bavinck, Reformed Dogmatics, vol. I, 304-305. 
First, the biblical concept of God can function as the conceptual starting point of natural theology. Suppose one begins with the biblical view of God as an almighty, eternal spirit, perfect in goodness and knowledge, and creator and sustainer of all things. Given this biblical concept of God, one could move on to consider the extent to which the existence of this being is a cogent conclusion from various a posteriori and a priori starting points of argumentation. In other words, one could begin natural theology with a clear concept of God derived from scripture and seek from there to prove on rational grounds that such a being exists, rather than let the concept of God emerge as a consequence of the reasoning of the theistic proofs. This is one way in which the Christian construction of theistic arguments might presuppose the biblical view of God, while at the same time taking seriously the logical work of constructing cogent arguments for the existence and nature of such a being. Of course, beginning with the biblical doctrine of God also directs our attention to the creative and providential acts of God as $\mathrm{He}$ is revealed in Scripture. It therefore allows us to see the universe and its fundamental features-the starting point of the empirical theistic arguments - as the product of the creative act of the triune God of redemption.

Secondly, by providing a biblical concept of God, Scripture provides a background system of theological belief relevant to the derivation of defeaters to our natural theological reasoning. Here Scripture provides a negative constraint on natural theological arguments, a kind of 'veto power' over natural theological reasoning. While this may be used to identify faulty premises, it can more importantly help identify false conclusions about the nature of God. Aristotle reasoned to the existence of a single supreme being limited in knowledge and power, and wholly unconcerned with human affairs. Epicurean natural theology in ancient Greece and deistic natural theology in modern philosophy both arrived at conclusions inconsistent with the immanence of God and his providential control of the world. Stoic natural theology could justify the immanence and providence of God but only by adopting a principle of an organic continuum that entailed the identity of God and creation. A biblical theology of God leads us in a different direction. According to Scripture, God exercises providential care over the details of the Universe. Unlike Aristotle's unmoved mover or the many gods of Greek religion, the God 
of the Bible is not finite in knowledge and power. But neither does God's infinite perfection make him identical to the universe. Scripture presents us with a clear ontological distinction between the creator and creation. God's immanence is not purchased at the price of His transcendence. While natural theology uncontrolled by biblical revelation has often resulted in a concept of God incompatible with the Christian concept of God, reason controlled by the deliverances of scripture can more consistently arrive at claims about God that are compatible with the biblical doctrine of God.

\section{CONCLUSION}

In this paper I have addressed two significant misunderstandings of what Plantinga and others have designated the 'Reformed objection' to natural theology. First, there is no connection between the Reformed endorsement of properly basic theistic belief and Reformed opposition to natural theology. The crucial issue for nineteenth- and twentieth-century Reformed critics of natural theology has been the purported autonomy of natural theology, that is, its allegedly constituting a theology of God independent of dogmatic theology and functioning as a rational preamble to dogmatics. Secondly, once we are clear about the real Reformed objection to natural theology, it is apparent that it does not involve an unqualified rejection of the project of developing theistic arguments. Natural theology may be pursued as a dogmatically situated activity of rational reflection on the Christian God as manifested in the works of creation and providence. While this view of natural theology permits an apologetic deployment of theistic arguments, its primary goal is to enlarge the Christian's knowledge of God and justify the instrumental role of reason within the system of dogmatic theology. 